\title{
ROLA CENTRALNEGO BIURA ŚLEDCZEGO POLICJI W WALCE Z PRZESTĘPCZOŚCIĄ ZORGANIZOWANĄ. ZARYS PROBLEMATYKI FUNKCJONOWANIA SŁUŻBY
}

\begin{abstract}
Celem artykułu jest zaprezentowanie Centralnego Biura Śledczego Policji jako służby właściwej w zakresie rozpoznawania, zwalczania i przeciwdziałania przestępczości zorganizowanej. Z uwagi na trudności eksplanacyjne związane z nieostrością pojęcia „,przestępczość zorganizowana", podjęta została próba zaprezentowania syntetycznej definicji w oparciu o poszczególne kryteria identyfikujące zjawisko.

We wstępie rozważań zaprezentowana została wykładnia terminologiczna podstawowych pojęć związanych z poruszanym zagadnieniem. Wobec pojawiających się nowych zagrożeń związanych z rozwojem cywilizacyjnym, w tym także technologicznym, zorganizowane grupy przestępcze wykazują aktywność w różnorodnych płaszczyznach życia społecznego. Intensyfikacja działalności zorganizowanych grup przestępczych wpływa zasadniczo na percepcję bezpieczeństwa w efekcie czego państwo podejmuje odpowiednie działania w przedmiocie wykrywania, zwalczania oraz przeciwdziałania tego typu zagrożeniom. W artykule wyznaczono główne obszary działalności zorganizowanych grup przestępczych również w wymiarze statystycznym. Przedstawiono ponadto proces legislacyjny towarzyszący tworzeniu się nowej jednostki oraz główne zmiany przepisów w ustawie o Policji.

Szczególnej uwadze poddano główne obszary działań zorganizowanych grup przestępczych: obszar kryminalny, gospodarczy i narkotykowy. Z uwagi na różnorodność podejmowanych działań przez zorganizowane grupy przestępcze, przedstawiony został katalog zadań niniejszej służby w oparciu o powyższą rodzajowość. Ponadto zaprezentowano zadania funkcjonariuszy Centralnego Biura Śledczego Policji w poszczególnych płaszczyznach działalności zorganizowanych grup przestępczych.

Konstatację powyższych rozważań stanowi próba przedstawienia zasadności powołania do życia omawianej służby z uwagi na dynamicznie rozwijającą się problematykę przestępczości zorganizowanej.
\end{abstract}

Słowa kluczowe: Centralne Biuro Śledcze Policji, przestępczość zorganizowana, przestępczość kryminalna, przestępczość narkotykowa, przestępczość ekonomiczna.

Zagadnienie bezpieczeństwa jest jednym z głównych obszarów badawczych oraz fundamentalnym elementem polityki państwa. W kontekście naukowym jest to temat niezwykle atrakcyjny z uwagi na swój interdyscyplinarny charakter. Możliwość rozpatrywania fenomenu bezpieczeństwa oraz właściwa deskrypcja zjawiska w oparciu o różne dziedziny nauk, niewątpliwie przyczynia się do poszerzania walorów poznawczych. W perspektywie

\footnotetext{
${ }^{1}$ Mgr Anna Maria Hernacka, doktorantka Uniwersytetu Kazimierza Wielkiego w Bydgoszczy, Wydział Humanistyczny, kierunek: Nauki o polityce.
} 
prowadzonej polityki przez państwo, odnieść należy się do szerokiego katalogu norm prawnych i instytucjonalnych wpływających na stan i poczucie bezpieczeństwa.

Z uwagi na zmianę percepcji bezpieczeństwa oraz zagrożeń wpływających negatywnie na jego odpowiedni poziom, ustawodawstwo nieustannie dostosowuje środki, narzędzia, techniki działań kompetentnych w tym zakresie organów i instytucji, wobec zmieniającej się rzeczywistości. Współcześnie, błędne byłoby podtrzymywanie w mocy przekonania, iż niebezpieczeństwa charakteru militarnego są jedynymi głównymi zagrożeniami w utrzymywaniu prawidłowego poziomu bezpieczeństwa państwa i obywateli. W dobie globalizacji, rozwoju technologicznego i rozszerzania się katalogu zagrożeń, wymienić można te, które trudno poddać jednoznacznej ocenie w oparciu o klasycznie ujmowane typologizacje bezpieczeństwa w kryterium przedmiotowym. Jednym z takich zagrożeń jest przestępczość zorganizowana i funkcjonowanie na wysoką skalę zorganizowanych grup przestępczych. Wobec narastającego problemu, jakim jest obecnie przestępczość zorganizowana, państwo zobowiązane jest wdrożyć takie instytucje i mechanizmy działań, które w sposób efektywny będą przeciwstawiać się temu zagrożeniu.

Przełomowym krokiem okazało się powołanie do życia Centralnego Biura Śledczego Policji. Aby prawidłowo identyfikować zadania, kompetencje omawianej instytucji, niniejsze rozważania należy rozpocząć od zaprezentowania definicji ,„przestępczości zorganizowanej”. Współcześnie nie funkcjonuje jednolite, syntetyczne ujęcie tego terminu. Niemniej jednak, na podstawie licznych i różnorodnych ujęć teoretycznych można podjąć próbę sprecyzowania jego istoty. O ile nie stanowi problemu zdefiniowanie ,,przestępczości”, o tyle zjawisko „,przestępczości zorganizowanej” jest problematyczne w jednoznacznej ocenie ze względu na niezrozumiałość terminologiczną ujęcia ,,zorganizowana”. Na podstawie art. 1 kodeksu karnego, można zaprezentować termin przestępczości, iż jest to pewien rodzaj „,czynu zabronionego pod groźbą kary przez ustawę obowiązującą w czasie jego popełnienia, bezprawnego, zawinionego, społecznie szkodliwego w stopniu wyższym niż znikomy”2. Natomiast poprzez słowo „,zorganizowany” rozumieć należy „taki, który potrafi dobrze rozplanować sobie zajęcia, pracę"3. Ponadto, zjawisko zorganizowanej przestępczości charakteryzuje się funkcjonowaniem pewnych nielegalnych ugrupowań, kolektywów, identyfikowanych ze zorganizowanymi grupami przestępczymi ${ }^{4}$.

Zatem ,,przestępczość zorganizowaną" należy identyfikować z działalnością zorganizowanych grup przestępczych, która w sposób niezgodny z prawem i zaplanowany, podejmuje czynności w celu uzyskania pewnych korzyści i zysków ${ }^{5}$. Na podstawie różnych ujęć definicyjnych wypracowanych przez liczne grono badaczy zjawiska, rysuje się pewien dualizm, na podstawie którego przyjąć można deskrypcje przestępczości zorganizowanej opartej o model mafijny oraz grupowy. Pierwszy z nich odnosi się do hierarchiczności zorganizowanej grupy przestępczej oraz prowadzenia ciągłej, długofalowej działalności prze-

\footnotetext{
${ }^{2}$ P. Kozłowska-Kalisz, Rozdziat I-Zasady odpowiedzialności karnej [w:] Kodeks karny. Komentarz, red. M. Mozgawa, Warszawa 2015, s. 26.

${ }^{3}$ E. Sobol (red.), Nowy stownik języka polskiego, Warszawa 2003, s. 1290.

${ }^{4}$ Z.B. Gądzik, Przestępstwo prania brudnych pieniędzy jako przejaw działalności zorganizowanych grup przestępczych [w:] Oblicza wspótczesnej przestępczości zorganizowanej, red. K. Laskowska, Białystok 2014, s. 43.

5 Ibidem.
} 
stępczej ${ }^{6}$. Ponadto, wskazuje się w tym ujęciu na liczne powiązania z gospodarką i polityką ${ }^{7}$. Drugi model, tzw. grupowy, prezentuje zorganizowaną grupę przestępezą jako organizację o dowolnej strukturze oraz swobodnym zakresie powiązań, powołanej w celu dokonania choćby jednego przestępstwa ${ }^{8}$.

Wobec stale wzrastającego zagrożenia bezpieczeństwa poprzez działalność zorganizowanych grup przestępczych, państwo zmuszone jest podjąć odpowiednie czynności efektywnie przeciwdziałające temu zjawisku. Jednym z takich działań jest kreacja kompetentnych w tym zakresie organów i instytucji ochrony bezpieczeństwa. Istotną trudnością w identyfikacji zorganizowanych grup przestępczych jest asymetryczność kierunków działań oraz elastyczność technik i czynności wobec zmieniającego się otoczenia. Niemniej jednak, głównymi i niezmiennymi obszarami działań zorganizowanej przestępczości jest przestępczość kryminalna, narkotykowa oraz gospodarcza. Świadczyć mogą o tym statystyki policyjne, których kształt zaprezentowany jest w poniższym zestawieniu.

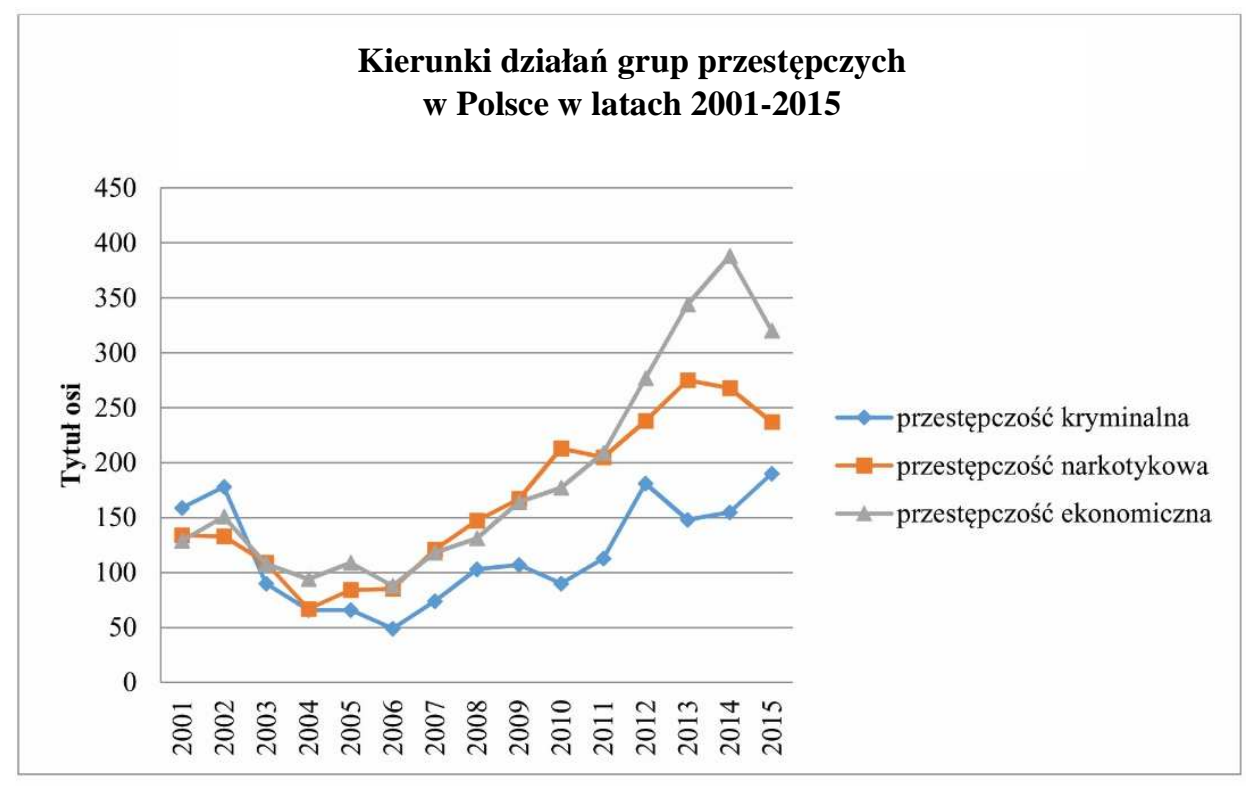

Źródło: opracowanie własne na podstawie raportów Policji, http://cbsp.policja.pl/cbs/do-pobrania/raporty-z-dzialalnosci/9890,Raporty-z-dzialalnosci.html

Po wielu latach funkcjonowania Centralnego Biura Śledczego Komendy Głównej Policji, stanowiącego jedynie komórkę organizacyjną Policji, zrodziła się idea powołania do życia nowej, odrębnej służby. Efektem tych działań było wyodrębnienie organizacyjne i utworzenie tym samym dnia 9 października 2014 r. Centralnego Biura Śledczego Policji 9

${ }^{6}$ K. Bułat, P. Czarniak, A. Gorzelak, K. Grabowski, M. Grzyb, M. Iwański i in., Kryminologia. Repetytorium, Warszawa 2013, s. 107.

7 Ibidem.

8 Ibidem.

${ }^{9}$ Historia CBŚP, http://cbsp.policja.pl/cbs/o-cbsp/historia/120311,Historia-CBSP.html (dostęp: 9.11.2016 r.). 
Na czele nowo powstałej jednostki stanął nadinspektor Igor Parfieniuk. Zmiany te determinowane były m.in. podnoszonymi zarzutami o braku odpowiednich środków i zaplecza organizacyjnego wobec przeciwdziałania przestępczości zorganizowanej, która była zjawiskiem dynamicznie się rozwijającym. Umiejscowienie Centralnego Biura Śledczego Policji w takich strukturach policyjnych skutkuje efektywnym wykonywaniem działań, a zatem pełnowymiarowego wypełniania założeń ustawy o Policji.

Ponadto, brak niezależności płaszczyzny finansowej, logistycznej oraz kadrowej jest zjawiskiem negatywnym w prawidłowym funkcjonowaniu instytucji i elementem utrudniającym wypełnianie obowiązków służbowych funkcjonariuszy ${ }^{10}$. W kontekście zmian w obszarze finansowym, zaznaczyć można wyraźną samodzielność Komendanta Centralnego Biura Śledczego Policji identyfikowanego jako samodzielnego dysponenta środków budżetowych III stopnia ${ }^{11}$. Analogiczne rozwiązanie ma zastosowanie wobec komendantów wojewódzkich, komendanta stołecznego czy szkół policyjnych ${ }^{12}$.

Tego typu uregulowanie otwiera możliwość kreowania osobistych jednostek organizacyjnych w oparciu o realne występujące potrzeby. W kontekście polityki kadrowej, szef Centralnego Biura Śledczego Policji dysponuje takimi samymi uprawnieniami wobec funkcjonariuszy jakimi władają komendanci wojewódzcy ${ }^{13}$. Samodzielność ta skutkuje odpowiednim zarządzaniem zasobami osobowymi.

Wobec zmian organizacyjnych, szczególną rolę przypisuje się zapleczu logistycznemu, którego dotychczasowy kształt był nieadekwatny do wypełnianej przez instytucję funkcji ${ }^{14}$. Zarówno specyfika pracy funkcjonariuszy Centralnego Biura Śledczego Policji jak i różnorodność działań oraz dynamika rozwoju przestępczości zorganizowanej, wymaga wdrożenia odpowiednich przekształceń $\mathrm{w}$ przedmiocie logistyki ${ }^{15}$.

Istotnym krokiem w implementacji zmian ustawy o Policji był projekt ustawy Klubu Parlamentarnego Prawo i Sprawiedliwość, przedłożony w dniu 13 marca 2013 r. marszałkowi Sejmu RP Ewie Kopacz ${ }^{16}$. Efektem działań prac legislacyjnych w związku z zapisami uwzględniającymi powołanie nowej jednostki, Centralnego Biura Śledczego Policji, było wejście w życie nowej ustawy o Policji.

W związku z powyższym do niniejszej ustawy dodano art. 5a w następującym brzmieniu:

„1. Centralne Biuro Śledcze Policji, zwane dalej »CBŚP «, jest jednostką organizacyjną Policji służby śledczej realizującą na obszarze całego kraju zadania w zakresie rozpoznawania, zapobiegania i zwalczania przestępczości zorganizowanej.

2. Komendant Centralnego Biura Śledczego Policji, zwany dalej »,Komendantem CBŚP«, jest organem Policji podległym Komendantowi Głównemu Policji, kieruje CBŚP i jest przełożonym policjantów CBŚP.

\footnotetext{
${ }^{10}$ Wypowiedzi na posiedzeniach Sejmu. Posiedzenie nr 63 w dniu 14.03.2014 (3. dzień obrad), http://www.sejm.gov.pl/sejm7.nsf/wypowiedz.xsp?posiedzenie=63\&dzien=3\&wyp=26\&symbol=RWYSTAPIENIA_WYP\&id=445 (dostęp: 9.11.2016 r.).

11 Ibidem.

12 Ibidem.

${ }^{13}$ Nie ma już CBŚ... Powstało Centralne Biuro Śledcze Policji, http://wpolityce.pl/kryminal/217270nie-ma-juz-cbs-powstalo-centralne-biuro-sledcze-policji (dostęp: 9.11.2016 r.).

${ }^{14}$ Wypowiedzi na posiedzeniach Sejmu. Posiedzenie nr $63 \mathrm{w}$ dniu 14.03.2014 r. (3. dzień obrad)...

15 Poselski projekt ustawy o zmianie ustawy o Policji i niektórych innych ustaw z dnia 13 marca 2013 r., http://www.adwokatura.pl/projekty-legislacyjne/ (dostęp: 9.11.2016 r.).

16 Ibidem.
} 
3. Siedzibą Komendanta CBŚP jest miasto stołeczne Warszawa.

4. Komendanta CBŚP powołuje, spośród oficerów Policji, i odwołuje minister właściwy do spraw wewnętrznych na wniosek Komendanta Głównego Policji.

5. Zastępców Komendanta CBŚP powołuje, spośród oficerów Policji, i odwołuje Komendant Główny Policji na wniosek Komendanta CBŚP.

6. W razie zwolnienia stanowiska Komendanta CBŚP Komendant Główny Policji, do czasu powołania nowego komendanta, powierza pełnienie obowiązków Komendanta CBŚP, na okres nie dłuższy niż 6 miesięcy, jednymi z jego zastępców bądź wyznaczonemu oficerowi Policji.

7. W celu realizacji zadań określonych w ust. 1 Komendant CBŚP współdziała z innymi jednostkami organizacyjnymi Policji oraz właściwymi organami i instytucjami, w tym innych państw"17.

Ważnym zabiegiem zastosowanym, w przedmiocie wyżej wymienionego aktu prawnego, jest uregulowanie zadań Centralnego Biura Śledczego Policji w art. 5a ust. 1. Istota zapisu polega przede wszystkim na sprowadzeniu kompetencji jednostki, w sferze rozpoznawania, zapobiegania i zwalczania przestępczości zorganizowanej, do poziomu ustawowego, a nie jedynie do zapisów w aktach wykonawczych ${ }^{18}$. Ponadto, przyjęcie przez parlament w dniu 26 czerwca 2014 r. ustawy o zmianie ustawy o Policji i niektórych innych ustaw, skutkuje również ważnym umocnieniem pozycji omawianej instytucji ${ }^{19}$. Przykładem tego jest zmiana dotychczasowego brzmienia art. 4 i uwzględnienie w nim Centralnego Biura Śledczego Policji jako służby śledczej ${ }^{20}$. Wcześniej obowiązujący dokument regulujący kwestie organizacyjne Policji, ujmował jedynie funkcjonowanie służby kryminalnej, prewencyjnej i wspomagającej ${ }^{21}$.

W kontekście podejmowanych czynności operacyjno-rozpoznawczych, Komendant wyposażony jest w kompetencje dotyczące m.in. ,,kontrolowanego przejęcia przedmiotów pochodzących z przestępstwa, kontrolowanego wręczenia korzyści majątkowej, przedłużania tych czynności i ich kontynuowania oraz przekazywania prokuratorowi zgromadzonych materiałów"22.

Poddając analizie kompetencje Centralnego Biura Śledczego Policji, należy wyodrębnić trzy główne obszary działań. Zgodnie z paragrafem 3, ust. 1, pkt 1 zarządzenia nr 54 Komendanta Głównego Policji z dnia 7 października 2014 r. w sprawie organizacji, rzeczowego i miejscowego zakresu działania oraz zasad współdziałania Centralnego Biura Śledczego Policji z innymi jednostkami organizacyjnymi Policji, do zakresu działań instytucji należy ,planowanie, koordynowanie i podejmowanie działań ukierunkowanych na rozpoznawanie i zwalczanie przestępczości zorganizowanej krajowej i międzynarodowej, w szczególności o charakterze kryminalnym, narkotykowym i ekonomicznym oraz jej

\footnotetext{
17 A. Babiński, Wybór aktów normatywnych z zakresu prawa policyjnego, wydanie XXIX, stan prawny na dzień 3.11.2014 r., Szczytno 2014, s. 8.

${ }_{18}$ Wypowiedzi na posiedzeniach Sejmu. Posiedzenie nr 63 w dniu 14.03.2014 (3. dzień obrad)...

${ }^{19}$ Powstanie CBŚP (nr 115/10.2014), „Policja” 997, http://www.gazeta.policja.pl/997/informacje/104284,Powstanie-CBSP-nr-115102014.html, dostęp: 11.11.2016 r.

20 Ibidem.

${ }^{21}$ Ustawa o Policji, art. 4 ust. 1 (Dz.U. nr 30, poz. 179).

${ }^{22}$ Kronika Sejmowa, Kancelaria Sejmu, nr 65 (790) Warszawa 2014, s. 12.
} 
zapobieganie"23. Na podstawie powyższego, w Polsce powszechnie wyodrębnia się trzy rodzaje przestępczości zorganizowanej: kryminalną, narkotykową i ekonomiczną ${ }^{24}$.

Pierwszym z obszarów wymienionych w niniejszym przepisie jest przestępczość kryminalna. Ten rodzaj przestępczości odnosi się przede wszystkim do takiego katalogu czynów zabronionych, wśród których wyodrębnić należy m.in. zabójstwa, porwania dla okupu, sutenerstwo, rozboje, kradzieże i legalizacje skradzionych samochodów, falsyfikacje środków płatniczych czy też nielegalny obrót bronią i materiałami wybuchowymi ${ }^{25}$. Podstawowym zadaniem Centralnego Biura Śledczego Policji jest identyfikacja zorganizowanych grup przestępczych, które prowadzą działalność przestępczą odznaczającą się wysokim poziomem brutalizacji ${ }^{26}$. Wymienić tu należy przede wszystkim zabójstwa, przestępstwa z użyciem broni palnej, wymuszenia rozbójnicze oraz windykację należności ${ }^{27}$. Ponadto, jednostka właściwa jest w zwalczaniu przestępstw mających związek z nielegalnym przemytem oraz obrotem broni palnej, amunicji, a także materiałów wybuchowych ${ }^{28}$. Centralne Biuro Śledcze Policji ma również za zadanie eliminowanie zorganizowanych grup przestępczych dokonujących kradzieży, przemytu i legalizacji pojazdów, jak również dokonywania kradzieży z włamaniem ${ }^{29}$. W katalogu podstawowych zadań należy również wskazać zwalczanie przestępstw związanych z uprowadzeniami dla okupu, wymuszaniem haraczy, prostytucją, zapobieganiem handlowi ludźmi ${ }^{30}$. Wobec nasilających się działań o charakterze terrorystycznym, jednostka ta właściwa jest w podejmowaniu czynności, mających na celu wykrywanie i zwalczanie zjawisk dotyczących terroru kryminalnego, terroryzmu oraz ekstremizmu ${ }^{31}$. Funkcjonariusze Centralnego Biura Śledczego Policji rozpoznają i neutralizują działalność zorganizowanych grup przestępczych zdominowanych przez reprezentantów mniejszości etnicznych ${ }^{32}$. Podejmowane czynności przez Centralne Biuro Śledcze Policji w kontekście zorganizowanej przestępczości kryminalnej, są kluczowe w perspektywie utrzymywania prawidłowego poziomu bezpieczeństwa. Efektywność wykonywanych zadań przez omawianą jednostkę, jest szczególnie istotne dla obywateli, ponieważ katalog przestępstw kryminalnych odnosi się do zagrożeń życia, zdrowia, wolności oraz mienia.

Drugi obszar podstawowych zadań Centralnego Biura Śledczego Policji stanowi przestępczość narkotykowa, związana przede wszystkim z produkcją, handlem oraz przemytem

${ }^{23}$ Zarządzenie nr 54 Komendanta Głównego Policji z dnia 7 października 2014 r. w sprawie organizacji, rzeczowego i miejscowego zakresu działania oraz zasad współdziałania Centralnego Biura Śledczego Policji z innymi jednostkami organizacyjnymi Policji, paragraf 3, ust. 1, pkt 1.

${ }^{24}$ I. Kochman, Przestępczość zorganizowana w Polsce $i$ jej zwalczanie, www.wspia.eu/file/ 20335/30-KOCHMAN+IZABELA.pdf (dostęp: 16.02.2017 r.).

${ }_{25}$ M. Moskal, Zagrożenia dla bezpieczeństwa wewnętrznego związane z przestępczościa zorganizowana w Polsce na poczatku XXI wieku, www.wspia.eu/file/20334/31-MOSKAL+MATEUSZ.pdf (dostęp: 16.02.2017 r.)

${ }_{26}$ A. Rosół (red.), ,Kwartalnik Policyjny”, 4/2014, s. 58.

27 Ibidem.

${ }^{28}$ Ibidem.

${ }^{29}$ Ibidem.

30 Ibidem.

31 Ibidem.

32 Ibidem. 
środków narkotykowych ${ }^{33}$. Katalog działań jednostki obejmuje rozpoznawanie i zwalczanie zorganizowanych grup przestępczych, których działalność przestępcza związana jest z produkcją i obrotem środkami odurzającymi zarówno w obrocie krajowym jak i zagranicznym $^{34}$. Funkcjonariusze, w celu podejmowania skutecznych czynności, współpracuja z międzynarodowymi instytucjami i służbami właściwymi w sprawach przeciwdziałania przestępczości o charakterze narkotykowym ${ }^{35}$. Ponadto, Centralne Biuro Śledcze Policji ujawnia i likwiduje miejsca produkcji środków odurzających, narkotyków syntetycznych ${ }^{36}$. Zarówno w perspektywie krajowej oraz międzynarodowej, przestępczość narkotykowa stanowi jeden z głównych celów politycznych w Europie ${ }^{37}$. Narkomania jest zjawiskiem dynamicznie rozwijającym się i dotyczy różnorodnych obszarów działalności takich jak m.in. posiadanie, produkcja, przemyt oraz handel ${ }^{38}$. Wyraźny wzrost przestępczości narkotykowej można odnotować w dobie transformacji ustrojowej Polski. Polska znajdowała się wówczas na drugim miejscu w klasyfikacji państw o najwyższym wskaźniku produkcji amfetaminy ${ }^{39}$. Skutkiem przemian społeczno-polityczno-gospodarczych było m.in. otwarcie granic pomiędzy wschodnią a zachodnią Europą, co miało niebagatelne znaczenie dla rozwoju przestępczości, szczególnie tej o charakterze narkotykowym ${ }^{40}$. Szczególnie niebezpieczne były narkotykowe grupy przestępcze, które odznaczały się szerokim wachlarzem powiązań międzynarodowych, a to pogłębiało problem efektywnego przeciwdziałania temu zjawisku, z uwagi na brak odpowiednich środków prawnych i instytucjonalnych ${ }^{41}$.

Trzeci katalog podejmowanych czynności przez Centralne Biuro Śledcze Policji związany jest z przestępczością ekonomiczną. Działania w tym obszarze odnoszą się przede wszystkim do wykrywania i przeciwdziałania formom przestępczości zorganizowanej ukierunkowanej na przestępczość celno-podatkową związaną z obrotem towarami obarczonych akcyzą oraz podatkiem VAT ${ }^{42}$. Ponadto, jednostka ta rozpoznaje i przeciwdziała przestępczości zorganizowanej, która czerpie korzyści poprzez wykorzystywanie i dystrybucję środków finansowych z Unii Europejskiej ${ }^{43}$. W kontekście przestępczej działalności ekonomicznej, Centralne Biuro Śledcze Policji przeciwdziała funkcjonowaniu przestępczości zorganizowanej w obszarze nielegalnego obrotu paliwami oraz działalności na rynkach finansowych - bankowych, ubezpieczeniowych, giełdowych, firm leasingowych ${ }^{44}$. Kluczowym zadaniem służby jest również wykrywanie i przeciwdziałanie korupcji, stanowiącej

${ }^{33}$ http://cbsp.policja.pl/cbs/o-cbsp/podstawowe-zadania/9889,Podstawowe-zadania.html

${ }^{34}$ Ibidem.

35 Ibidem.

${ }^{36}$ Ibidem.

${ }^{37}$ M. Struzik, Przestęstwa zwiąane z narkotykami. Próba zdefiniowania zjawiska, http://www. narkomania.org.pl/czytelnia/przestepstwa-zwiazane-z-narkotykami-proba-zdefiniowania-zjawiska/ (dostęp: 15.02.2017 r.).

${ }^{38}$ E. Bandoch, Zagrożenia młodzieży na terenie miejscowości Góra, Warszawa 2008, s. 54.

39 W. Pływaczewski, J. Świerczewski (red.), Policja Polska wobec przestępczości zorganizowanej, Szczytno 1996, s. 29.

40 Ibidem.

41 Ibidem, s. 30.

42 W. Mądrzejowski, Przestępczość zorganizowana. System zwalczania, Warszawa 2015, s. 159.

43 Ibidem.

${ }^{44}$ Ibidem. 
podstawowe zagrożenie w prawidłowym funkcjonowaniu gospodarki państwa ${ }^{45}$. Do podstawowych zadań Centralnego Biura Śledczego Policji, ustawodawca zaliczył również zadania z zakresu zwalczania cyberprzestępczości ${ }^{46}$. Współcześnie stanowi to jeden $\mathrm{z}$ elementarnych zagrożeń bezpieczeństwa każdej sfery życia społecznego. Zarówno samo zjawisko jak i groźba dokonania tego typu zagrożenia, oddziałuje na katalog różnorodnych niebezpieczeństw odnoszących się do ustroju oraz gospodarki państw, jak również organizacji międzynarodowych ${ }^{47}$.

Odnosząc się do tak szerokiej i zróżnicowanej w swojej formie rodzajowości zagrożeń jakie niesie ze sobą przestępczość zorganizowana, stwierdzić można, iż wyodrębnienie organizacyjne Centralnego Biura Śledczego Policji ze struktur Komendy Głównej Policji, uznać należy za zabieg niezbędny i efektywny. Rozwijające się dynamicznie zagrożenia bezpieczeństwa, w tym szczególnie przestępczości zorganizowanej, wpływają nieustannie na dostosowywanie się instytucji i służb do nowej rzeczywistości.

Eskalacja problemu przestępczości zorganizowanej wymaga od państwa aktywizacji w obszarze kreacji nowych norm prawnych oraz powoływania nowych instytucji, służb odpowiedzialnych za zwalczanie tego negatywnego zjawiska. Jest to szczególnie istotne z uwagi na właściwości zorganizowanych grup przestępczych odznaczających się elastycznością działań i szerokim, różnorodnym katalogiem środków i narzędzi dokonywania przestępstw. Wobec współczesnych wyzwań bezpieczeństwa państwa i obywateli, z całą pewnością należy stwierdzić, iż optyka działań Centralnego Biura Śledczego Policji, w znaczącym stopniu przyczynia się do poprawy stanu bezpieczeństwa, co z kolei wpływa pozytywnie na percepcję jakości przestrzeni publicznej i poczucie bezpieczeństwa obywateli. Świadczyć mogą o tym doniesienia mass mediów o zlikwidowanych zorganizowanych grupach przestępczych oraz oficjalne statystyki policyjne. Na podstawie corocznych raportów sporządzanych przez Policję stwierdzić można, iż Centralne Biuro Śledcze Policji sprawnie i skutecznie podejmuje właściwe dla siebie czynności rozpoznawcze i przeciwdziałające zagrożeniu przestępczości zorganizowanej.

\section{LITERATURA}

[1] Babiński A., Wybór aktów normatywnych z zakresu prawa policyjnego, wydanie XXIX, stan prawny na dzień 3.11.2014 r., Szczytno 2014.

[2] Bandoch E., Zagrożenia młodzieży na terenie miejscowości Góra, Warszawa 2008.

[3] Bułat K., Czarniak P., Gorzelak A., Grabowski K., Grzyb M., Iwański M. i in., Kryminologia. Repetytorium, Warszawa 2013.

[4] Gądzik Z.B., Przestępstwo prania brudnych pieniędzy jako przejaw działalności zorganizowanych grup przestępczych [w:] Oblicza wspótczesnej przestępczości zorganizowanej, red. K. Laskowska, Białystok 2014.

[5] Grubicka J., Przeciwdziałanie wiktymizacji zagrożeń internetowych - bezpieczeństwo [w:] Acta Pomerania, red. T. Maciejewski, T. Biernat, J. Gierszewski, nr 3, 2011.

[6] Historia CBŚP, http://cbsp.policja.pl/cbs/o-cbsp/historia/120311,Historia-CBSP.html (dostęp: 9.11.2016 r.).

45 Ibidem.

46 Ibidem.

47 J. Grubicka, Przeciwdziatanie wiktymizacji zagrożeń internetowych - bezpieczeństwo [w:] Acta Pomerania, red. T. Maciejewski, T. Biernat, J. Gierszewski, nr 3, 2011, s. 156. 
[7] http://cbsp.policja.pl/cbs/o-cbsp/podstawowe-zadania/9889,Podstawowe-zadania.html.

[8] Kochman I., Przestępczość zorganizowana w Polsce i jej zwalczanie, www.wspia. eu/file/20335/30-KOCHMAN+IZABELA.pdf (dostęp: 16.02.2017 r.).

[9] Kozłowska-Kalisz P., Rozdziat I - Zasady odpowiedzialności karnej [w:] Kodeks karny. Komentarz, red. M. Mozgawa, Warszawa 2015.

[10] Kronika Sejmowa, Kancelaria Sejmu, nr 65 (790) Warszawa 2014.

[11] Mądrzejowski W., Przestępczość zorganizowana. System zwalczania, Warszawa 2015.

[12] Moskal M., Zagrożenia dla bezpieczeństwa wewnętrznego zwiazane z przestępczościa zorganizowana w Polsce na poczatku XXI wieku, www.wspia.eu/file/20334/31-MOSKAL+ MATEUSZ.pdf (dostęp: 16.02.2017 r.).

[13] Nie ma już CBŚ... Powstało Centralne Biuro Śledcze Policji, http://wpolityce.pl/kryminal/ 217270-nie-ma-juz-cbs-powstalo-centralne-biuro-sledcze-policji (dostęp: 9.11.2016 r.).

[14] Pływaczewski W., Świerczewski J. (red.), Policja Polska wobec przestępczości zorganizowanej, Szczytno 1996.

[15] Poselski projekt ustawy o zmianie ustawy o Policji i niektórych innych ustaw z dnia 13 marca 2013 r., http://www.adwokatura.pl/projekty-legislacyjne/ (dostęp: 9.11.2016 r.).

[16] Powstanie CBŚP (nr 115/10.2014), „Policja” 997, http://www.gazeta.policja.pl/997/informacje/104284,Powstanie-CBSP-nr-115102014.html (dostęp: 11.11.2016 r.).

[17] Sobol E. (red.), Nowy słownik języka polskiego, Warszawa 2003.

[18] Struzik M., Przestępstwa zwiąane z narkotykami. Próba zdefiniowania zjawiska, http://www.narkomania.org.pl/czytelnia/przestepstwa-zwiazane-z-narkotykami-probazdefiniowania-zjawiska/ (dostęp: 15.02.2017 r.).

[19] Ustawa z 6 kwietnia 1990 r. o Policji (tekst jedn. Dz.U. z 2017 r., poz. 2067).

[20] Wypowiedzi na posiedzeniach Sejmu. Posiedzenie nr 63 w dniu 14-03-2014 (3. dzień ob$\mathrm{rad}$ ), http://www.sejm.gov.pl/sejm7.nsf/wypowiedz.xsp?posiedzenie=63\&dzien=3\&wyp= 26\&symbol=RWYSTAPIENIA_WYP\&id=445 (dostęp: 9.11.2016 r.).

[21] Zarządzenie nr 54 Komendanta Głównego Policji z dnia 7 października 2014 r. w sprawie organizacji, rzeczowego i miejscowego zakresu działania oraz zasad współdziałania Centralnego Biura Śledczego Policji z innymi jednostkami organizacyjnymi Policji, paragraf 3 , ust. 1, pkt 1 .

\section{THE ROLE OF CENTRAL POLICE INVESTIGATION BUREAU IN THE FIGHT AGAINST ORGANIZED CRIME. AN OUTLINE OF THE FUNCTIONING OF THE SERVICE}

The aim of this article is to present the Central Police Investigation Bureau as a competent service in the field of identifying, combating and counteracting organized crime. Due to the explanation difficulties associated with the blurred of the term "organized crime" an attempt was made to present a synthetic definition based on individual criteria identifying the phenomenon.

In the foreground the terminological interpretation of the basic concepts related to the subject was presented. In the face of new threats related to the progress of civilization, including technology, organized crime groups show activity in various areas of social life. Intensification of the activities of organized crime groups has a fundamental impact on the perception of security, thereupon the state entertains appropriate actions in the area of detention, combating and counteracting threats. The article identifies the main area of activity of organized crime 
also in the statistical dimension. Moreover, the legislative process related to the creation of the new unit and the main changes in the law of the Police act was presented.

Particular attention has been paid to the main areas of activities of organized crime groups: criminal, economic and drugs. Due to the variety of activities undertaken by organized crime groups, the catalog of the tasks of this service was presented on the above generic type. Furthermore, the tasks of officers of the Central Police Investigation Bureau in particular levels of activities of organized criminal groups were presented. The conclusion of the above considerations is an attempt to present the validity of creating the service in due to the dynamic developing problem of organized crime.

Keywords: Central Police Investigation Bureau, crime groups: criminal, economic and drugs.

DOI: 10.7862/rz.2017.hss.45

Przestano do redakcji: luty 2017 r. Przyjęto do druku: wrzesień 2017 r. 